\title{
Air pollution, pollens, and daily admissions for asthma in London 1987-92
}

\author{
H R Anderson, A Ponce de Leon, J M Bland, J S Bower, J Emberlin, D P Strachan
}

\begin{abstract}
Background-A study was undertaken to investigate the relationship between daily hospital admissions for asthma and air pollution in London in 1987-92 and the possible confounding and modifying effects of airborne pollen.

Methods-For all ages together and the age groups 0-14, 15-64 and 65+ years, Poisson regression was used to estimate the relative risk of daily asthma admissions associated with changes in ozone, sulphur dioxide, nitrogen dioxide and particles (black smoke), controlling for time trends, seasonal factors, calendar effects, influenza epidemics, temperature, humidity, and autocorrelation. Independent effects of individual pollutants and interactions with aeroallergens were explored using two pollutant models and models including pollen counts (grass, oak and birch).
\end{abstract}

Results-In all-year analyses ozone was significantly associated with admissions in the 15-64 age group (10 ppb eight hour ozone, $3.93 \%$ increase), nitrogen dioxide in the 0-14 and 65+ age groups (10 ppb 24 hour nitrogen dioxide, $1.25 \%$ and $2.96 \%$, respectively), sulphur dioxide in the $0-14$ age group $\left(10 \mu \mathrm{g} / \mathrm{m}^{3} \quad 24\right.$ hour sulphur dioxide, $1.64 \%$ ), and black smoke in the $65+$ age group $\left(10 \mu \mathrm{g} / \mathrm{m}^{3}\right.$ black smoke, $5.60 \%$ ). Significant seasonal differences were observed for ozone in the 0-14 and 15-64 age groups, and in the 0-14 age group there were negative associations with ozone in the cool season. In general, cumulative lags of up to three days tended to show stronger and more significant effects than single day lags. In twopollutant models these associations were most robust for ozone and least for nitrogen dioxide. There was no evidence that the associations with air pollutants were due to confounding by any of the pollens, and little evidence of an interaction between pollens and pollution except for synergism of sulphur dioxide and grass pollen in children $(p<0.01)$.

Conclusions-Ozone, sulphur dioxide, nitrogen dioxide, and particles were all found to have significant associations with daily hospital admissions for asthma, but there was a lack of consistency across the age groups in the specific pollutant. These associations were not explained by confounding by airborne pollens nor was there convincing evidence that the effects of air pollutants and airborne pollens interact in causing hospital admissions for asthma.

(Thorax 1998;53:842-848)

Keywords: air pollution; pollen; asthma

It is widely believed that current levels of outdoor air pollution may provoke or exacerbate asthma. This is not surprising because a characteristic aspect of asthma is a tendency towards hyperreactivity to inhaled environmental gases, particles, and allergens. Experimental studies in animals and humans have shown that commonly measured pollutants including ozone $\left(\mathrm{O}_{3}\right)$, sulphur dioxide $\left(\mathrm{SO}_{2}\right)$, respirable particles, and nitrogen dioxide $\left(\mathrm{NO}_{2}\right)$ all have the potential to aggravate asthma by either direct irritation or by enhancing the effects of allergens to which the individual is sensitive. ${ }^{1-4}$ An effect of air pollution on symptoms or use of medications has been reported mainly from areas with high levels of oxidant pollution ${ }^{5-7}$ and some studies have only observed small changes in lung function, similar to those experienced by nonasthmatic subjects. ${ }^{2}$ It is plausible that such effects, if occurring in an asthmatic with already compromised lung function, could lead to an increase in use of primary care or hospital services. Exposure to aeroallergens (pollens, fungal spores) is related to weather conditions and is a potential confounder in analyses of the effects of air pollution on daily hospital admissions for asthma. Experimental evidence suggests that the effects of aeroallergens may be increased by exposure to air pollution ${ }^{8-10}$ but the importance of this biological interaction at the population level is unknown.

Analyses of daily time series of emergency hospital attendance or admissions for asthma offer a convenient method of testing the hypothesis that air pollution provokes asthma in the population at large. Taken overall, existing studies lack consistency as to the presence of effects or, where effects have been observed, the type of pollutant. ${ }^{2}$ Few studies have addressed the issue of confounding or effect modification by pollens or examined associations in children, a subject of particular popular concern.

In this paper we attempt to address all of these questions in the context of London from 1987 to 1992 . We use Poisson regression techniques to examine the association between air pollution $\left(\mathrm{O}_{3}, \mathrm{NO}_{2}, \mathrm{SO}_{2}\right.$, and black smoke) and daily emergency admissions for asthma in children, adults (15-64) and the elderly $(65+)$. We examine the possible confounding effect of airborne pollens and test the hypothesis raised by chamber studies $^{8-10}$ that there is an interaction 
Table 1 Summary data for daily asthma admissions, meteorological, and air pollution variables

\begin{tabular}{|c|c|c|c|c|c|c|c|c|c|c|c|c|}
\hline \multirow[b]{2}{*}{ Variable } & \multirow[b]{2}{*}{$\begin{array}{l}\text { Days of } \\
\text { observations }\end{array}$} & \multirow[b]{2}{*}{ Mean } & \multirow[b]{2}{*}{$S D$} & \multicolumn{9}{|c|}{ Percentile } \\
\hline & & & & Min & 5 th & $10 t h$ & $25 t h$ & $50 t h$ & 75 th & 90th & 95 th & $\operatorname{Max}$ \\
\hline \multicolumn{13}{|l|}{ Asthma admissions/day } \\
\hline All ages & 1796 & 35.1 & 15.3 & 3 & 15 & 18 & 24 & 33 & 43 & 54 & 64 & 109 \\
\hline $0-14$ years & 1796 & 19.5 & 11.1 & 1 & 6 & 8 & 12 & 17 & 25 & 34 & 40 & 85 \\
\hline $15-64$ years & 1796 & 13.1 & 6.3 & 1 & 5 & 6 & 9 & 12 & 17 & 21 & 25 & 46 \\
\hline $65+$ years & 1796 & 2.6 & 1.8 & 1 & 1 & 1 & 1 & 2 & 3 & 5 & 6 & 12 \\
\hline Mean temperature $\left({ }^{\circ} \mathrm{C}\right)$ & 1796 & 12.3 & 5.2 & -5 & 4 & 6 & 8 & 12 & 16 & 20 & 21 & 29 \\
\hline Relative humidity (\%) & 1796 & 72.1 & 10.2 & 40 & 54 & 58 & 65 & 72 & 80 & 86 & 89 & 96 \\
\hline $\mathrm{O}_{3}$, maximum $8 \mathrm{~h}$ average $(\mathrm{ppb})$ & 1613 & 15.5 & 10.9 & 1 & 2 & 4 & 8 & 14 & 21 & 28 & 36 & 74 \\
\hline $\mathrm{O}_{3}$, maximum $1 \mathrm{~h}(\mathrm{ppb})$ & 1677 & 20.6 & 13.2 & 0 & 3 & 5 & 11 & 20 & 27 & 36 & 45 & 94 \\
\hline $\mathrm{NO}_{2}, 24 \mathrm{~h}$ average $(\mathrm{ppb})$ & 1782 & 37.2 & 12.3 & 14 & 22 & 25 & 30 & 36 & 42 & 50 & 58 & 182 \\
\hline $\mathrm{NO}_{2}$, maximum $1 \mathrm{~h}$ average (ppb) & 1782 & 57.2 & 23.0 & 21 & 35 & 38 & 44 & 52 & 64 & 81 & 98 & 370 \\
\hline Black smoke, $24 \mathrm{~h}$ average $\left(\mu \mathrm{g} / \mathrm{m}^{3}\right)$ & 1793 & 14.6 & 7.0 & 3 & 7 & 8 & 10 & 13 & 18 & 22 & 26 & 95 \\
\hline $\mathrm{SO}_{2}, 24 \mathrm{~h}$ average $\left(\mu \mathrm{g} / \mathrm{m}^{3}\right)$ & 1793 & 32.0 & 11.7 & 9 & 16 & 18 & 24 & 31 & 38 & 46 & 52 & 100 \\
\hline Birch pollen $\left(\text { grains } / \mathrm{m}^{3}\right)^{1}$ & $252 / 915$ & 18 & 42 & 1 & 1 & 1 & 1 & 3 & 18 & 40 & 94 & 406 \\
\hline Grass pollen $\left(\text { grains } /^{\beta}\right)^{1}$ & $600 / 915$ & 21 & 37 & 1 & 1 & 1 & 2 & 6 & 18 & 68 & 104 & 293 \\
\hline Oak pollen $\left(\text { grains } / \mathrm{m}^{3}\right)^{1}$ & $207 / 915$ & 14 & 28 & 1 & 1 & 1 & 1 & 3 & 13 & 41 & 73 & 213 \\
\hline
\end{tabular}

${ }^{1}$ For warm season only. Number of days when counts were above zero.

between pollens and pollution effects. This work was part of a multi city European project (Air Pollution and Health: a European Approach (APHEA)) which used a standardised approach to the data assembly and statistical analysis. ${ }^{11-13}$ A meta-analysis of selected asthma admissions results from APHEA has been published $^{14}$ and elsewhere ${ }^{15}$ we have reported the results for all respiratory admissions, but not specifically for asthma. The published results for all respiratory diagnoses ${ }^{15}$ do not address possible confounding or effect modification by aeroallergens.

\section{Methods}

The sources of health and air pollution data and the way in which the database was constructed for analysis have been described in detail elsewhere. ${ }^{15}$ This followed the procedures adopted by APHEA ${ }^{11}$ All air pollution variables were obtained from routine monitors sited to measure urban background concentrations. Ozone concentrations were measured by the ultraviolet absorption technique at a single background monitor in inner London and expressed as eight hour (09.00-17.00 hours) and maximum one hour averages. Nitrogen dioxide concentrations were measured by the chemiluminescence method at two urban background sites in inner London and expressed as one hour maximum and daily averages. Daily average concentrations of particles were measured using the black smoke (BS) method at four monitors in central, north, northeast, and south London; this method measures only black particles of less than $4.5 \mu \mathrm{m}$ diameter. ${ }^{16}$ Daily average concentrations of $\mathrm{SO}_{2}$ were obtained from the same four sites using the acidimetric bubbler system. If up to two stations did not provide data we used a regression method to obtain an estimate of the average values across the four stations on each day. ${ }^{17}$ Mean 24 hour temperature and humidity were calculated from data obtained from Holborn in central London.

The airborne pollen concentrations were monitored on the flat unobstructed roof of a seven storey building in North London using a Burkard volumetric spore trap. This draws air through a critical orifice at $10 \mathrm{l} / \mathrm{min}$ onto a tape on a rotating drum (speed $2 \mathrm{~mm} / \mathrm{h}$ ) coated with a smooth adhesive mixture of Vaseline and paraffin wax to provide a time related sample of airborne material. The tape is stained with basic fuschin and examined under $\times 400$ magnification. Pollen grains and spores are identified with as much taxonomic detail as possible and a 24 hour average for each taxon is compiled from 12 two hour samples. This technique of pollen and spore monitoring is the standard adopted by the British Aerobiology Federation for use by the National Pollen Network. Daily counts for birch, grass, and oak are used in this analysis.

For the period April 1987 to February 1992 inclusive, counts of daily emergency admissions for asthma (ICD9 493 coded at discharge) to all National Health Service hospitals in London were obtained from the Hospital Episode System. This covers the great majority of emergency admissions for acute medical conditions such as asthma. It does not include attendance at hospital emergency departments which do not result in admission.

The statistical analysis followed the approach developed by APHEA which has been described elsewhere. ${ }^{12}$ Details of the analysis of the London admissions data for this period were described in our previous paper on all respiratory admissions ${ }^{15}$ ) but are briefly summarised here. The general approach was to use Poisson regression to model the daily counts of asthma admissions, taking account of overdispersion and autocorrelation. We first controlled for time trends, seasonal cycles, days of the week, public holidays, and influenza epidemics. The residuals from this process were then examined in relation to temperature and humidity to identify the lag (if any) with the strongest effect and the transformation (if any) which gave the best fit. The last stage in the development of the basic model was to correct for the remaining autocorrelation of the residuals. The final model was checked and revised as necessary using autocorrelation functions, Durbin-Watson statistics, plots of fitted values and residuals, and periodograms. A log linear model with autoregressive Poisson errors was then fitted to the data. No transformation of the pollutant variable was used.

Our a priori hypothesis concerned associations with pollution on the same or previous 
Table 2 Associations between air pollution and daily asthma admissions in London 1987-92. Percentage increase/decrease (95\% confidence intervals). The most significant single day $\left(l_{x}\right)$ and cumulative day $\left(l_{0 .}\right)$ lags are shown

\begin{tabular}{|c|c|c|c|c|c|c|c|c|c|c|}
\hline $\begin{array}{l}\text { Age } \\
\text { group } \\
\text { (years) }\end{array}$ & Season & $\begin{array}{l}8 \text { h ozone } \\
\text { Single lag }\end{array}$ & $\begin{array}{l}8 \text { h ozone } \\
\text { Cumulative lag }\end{array}$ & $\begin{array}{l}24 \mathrm{~h} \mathrm{NO} \\
\text { Single lag }\end{array}$ & & $\begin{array}{l}24 \mathrm{hNO}_{2} \\
\text { Cumulative lag }\end{array}$ & $\begin{array}{l}24 \mathrm{~h} \mathrm{SO} \mathrm{S}_{2} \\
\text { Single lag }\end{array}$ & $\begin{array}{l}24 \mathrm{~h} \mathrm{SO} \mathrm{SO}_{2} \\
\text { Cumulative lag }\end{array}$ & $\begin{array}{l}24 h B S \\
\text { Single lag }\end{array}$ & $\begin{array}{l}24 \mathrm{hBS} \\
\text { Cumulative la }\end{array}$ \\
\hline \multirow[t]{3}{*}{$0-14$} & Whole year & $\begin{array}{l}0.17 \\
-1.56,1.94\end{array}$ & $\begin{array}{ll}0.49 & 1_{02} \\
-1.7,2.73 & \end{array}$ & $\begin{array}{l}1.25^{\star} \\
0.3,2.2\end{array}$ & $1_{2}$ & $\begin{array}{ll}1.77^{\star \star} & 1_{03} \\
0.39,3.18 & \end{array}$ & $\begin{array}{ll}1.64^{\star} & 1_{1} \\
0.29,3.01\end{array}$ & $\begin{array}{ll}2.04^{\star} & 1_{03} \\
0.29,3.83 & \end{array}$ & $\begin{array}{ll}0.58 & 1_{2} \\
-1.27,2.46\end{array}$ & $\begin{array}{ll}0.88 & 1 \\
-1.85,3.7\end{array}$ \\
\hline & Warm season & $\begin{array}{l}1.48 \\
-0.51,3.50\end{array}$ & $\begin{array}{ll}2.69^{\star} & 1_{02} \\
0.21,5.22 & \end{array}$ & $\begin{array}{l}1.42 \\
-0.3,3.17\end{array}$ & $1_{2}$ & $\begin{array}{ll}3.01^{\star} & 1_{03} \\
3.8,5.72 & \end{array}$ & $\begin{array}{ll}3.33^{\star \star} & 1_{1} \\
1.09,5.63\end{array}$ & $\begin{array}{ll}3.40^{\star} & 1_{02} \\
0.41,6.48 & \end{array}$ & $\begin{array}{ll}-1.33 & 1_{2} \\
-5.35,2.87\end{array}$ & $\begin{array}{l}-4.13 \\
-10.18,2.32\end{array}$ \\
\hline & Cool season & $\begin{array}{l}-2.95^{\star} \\
-5.80,-0.02^{1}\end{array}$ & $\begin{array}{l}-5.75^{\star \star} \\
-9.4,-1.95\end{array} 1_{02}$ & $\begin{array}{l}1.18^{\star} \\
0.02,2.35\end{array}$ & $1_{2}$ & $\begin{array}{l}1.22 \\
-0.48,2.96\end{array}$ & $\begin{array}{l}0.56 \quad 1_{1} \\
-1.16,2.32\end{array}$ & $\begin{array}{l}1.24 \\
-0.95,3.49\end{array}$ l $^{1_{02}}$ & $\begin{array}{l}1.08 \\
-0.98,3.19\end{array}$ & $\begin{array}{l}2.09 \\
-0.99,5.25\end{array}$ \\
\hline \multirow[t]{3}{*}{$15-64$} & Whole year & $\begin{array}{l}3.93^{\star \star \star} \\
1.77,6.15\end{array}$ & $\begin{array}{ll}3.37^{\star \star} & 1_{02} \\
0.7,6.12 & \end{array}$ & $\begin{array}{l}0.95 \\
-0.26,2.17\end{array}$ & $1_{0}$ & $\begin{array}{l}0.99 \quad 1_{01} \\
-0.36,3.36\end{array}$ & $\begin{array}{l}-0.69 \quad 1_{2} \\
-2.28,0.94\end{array}$ & $\begin{array}{l}-0.71 \\
-2.69,1.30\end{array}$ & $\begin{array}{ll}0.61 & 1_{0} \\
-1.73,3.01\end{array}$ & $\begin{array}{l}0.47 \\
-2.17,3.18\end{array}$ \\
\hline & Warm season & $\begin{array}{ll}4.25^{\star \star \star} & 1_{1} \\
1.83,6.74 & \end{array}$ & $\begin{array}{ll}3.18^{\star \star} & 1_{02} \\
0.21,6.25 & \end{array}$ & $\begin{array}{l}0.46 \\
-1.70,2.67\end{array}$ & $1_{0}$ & $\begin{array}{l}0.05 \quad 1_{01} \\
-2.45,2.61\end{array}$ & $\begin{array}{l}-1.39 \quad 1_{2} \\
-3.97,1.27\end{array}$ & $\begin{array}{l}-2.2 \\
-5.46,11.8^{1_{02}}\end{array}$ & $\begin{array}{l}1.59 \\
-3.81,7.30\end{array}$ & $\begin{array}{l}-0.78 \\
-7.01,5.86\end{array}$ \\
\hline & Cool season & $\begin{array}{l}2.98 \quad l_{1} \\
-0.61,6.70\end{array}$ & $\begin{array}{l}3.74 \\
-0.88,8.57\end{array}$ & $\begin{array}{l}1.21 \\
-0.22,2.5\end{array}$ & $1_{0}$ & $\begin{array}{l}1.43 \\
-0.18,3.06\end{array}$ & $\begin{array}{l}-0.24 \quad 1_{2} \\
-2.28,1.84\end{array}$ & $\begin{array}{l}0.20 \quad 1_{02} \\
-2.28,2.74\end{array}$ & $\begin{array}{l}0.41 \\
-2.16,3.04\end{array}$ & $\begin{array}{l}0.72 \\
-1.28,3.71\end{array}$ \\
\hline \multirow[t]{3}{*}{$65+$} & Whole year & $\begin{array}{l}2.67 \quad 1_{2} \\
-1.66,7.20\end{array}$ & $\begin{array}{l}-2.64 \quad 1_{01} \\
-6.93,1.86\end{array}$ & $\begin{array}{l}2.96^{\star \star} \\
0.67,5.31\end{array}$ & $1_{2}$ & $\begin{array}{l}3.14 \quad 1_{03} \\
-0.04,6.42\end{array}$ & $\begin{array}{l}2.82 \quad 1_{2} \\
-0.82,5.96\end{array}$ & $\begin{array}{l}3.06 \quad-0.72,6.98^{1_{03}} \\
-0.04\end{array}$ & $\begin{array}{ll}5.60^{\star} & 1_{2} \\
1.09,10.31\end{array}$ & $\begin{array}{l}8.61^{\star \star} \\
2.39,15.2\end{array}$ \\
\hline & Warm season & $\begin{array}{l}3.68 \quad 1_{2} \\
-1.12,8.71)\end{array}$ & $\begin{array}{l}0.31 \quad 1_{01} \\
-4.63,5.31\end{array}$ & $\begin{array}{l}1.89 \\
-2.41,6.38\end{array}$ & $1_{2}$ & $\begin{array}{l}-1.76 \quad 1_{03} \\
-7.27,4.07\end{array}$ & $\begin{array}{l}-2.62 \quad 1_{2} \\
-7.31,2.31\end{array}$ & $\begin{array}{l}-4.27 \quad 1_{03} \\
-9.89,1.71\end{array}$ & $\begin{array}{l}7.46 \quad 1_{2} \\
-3.42,19.57\end{array}$ & $\begin{array}{l}2.99 \\
-11.11,19.08\end{array}$ \\
\hline & Cool season & $\begin{array}{l}0.14 \quad l_{2} \\
-6.87,7.68\end{array}$ & $\begin{array}{l}-9.0 \quad 1_{01} \\
-16.0,1.42\end{array}$ & $\begin{array}{l}3.52^{\star} \\
0.81,6.30\end{array}$ & $1_{2}$ & $\begin{array}{ll}5.57^{\star \star} & 1_{03} \\
1.85,9.43\end{array}$ & $\begin{array}{l}5.85^{\star \star} \\
1.81,10.05^{1}\end{array}$ & $\begin{array}{l}7.28^{\star \star} \\
2.19,12.62^{1_{03}}\end{array}$ & $\begin{array}{l}4.20 \\
-0.81,9.46\end{array}$ & $\begin{array}{l}7.91^{\star} \\
0.98,15.32\end{array}$ \\
\hline \multirow[t]{3}{*}{ All ages } & Whole year & $\begin{array}{l}6.90 \quad 1_{1} \\
-0.07,1.02\end{array}$ & $\begin{array}{l}0.42 \\
-1.31,2.17\end{array}$ & $\begin{array}{l}1.25^{\star \star \star} \\
0.49,2.02\end{array}$ & $1_{2}$ & $\begin{array}{ll}2.05^{\star \star} & 1_{03} \\
0.96,3.15 & \end{array}$ & $\begin{array}{ll}1.64^{\star} & 1_{1} \\
0.54,2.75 & \end{array}$ & $\begin{array}{ll}2.75^{\star \star \star} & 1_{03} \\
1.22,4.30 & \end{array}$ & $\begin{array}{l}1.22 \quad 1_{2} \\
-0.31,2.78\end{array}$ & $\begin{array}{l}2.35^{\star} \\
0.16,4.58\end{array}$ \\
\hline & Warm season & $\begin{array}{ll}2.21^{\star \star} & 1_{1} \\
0.62,3.82\end{array}$ & $\begin{array}{ll}2.10^{\star} & 1_{02} \\
0.13,4.10 & \end{array}$ & $\begin{array}{l}1.15 \\
-0.25,2.57\end{array}$ & $1_{2}$ & $\begin{array}{l}1.54{ }^{1} 1_{03} \\
-0.54,3.67\end{array}$ & $\begin{array}{ll}2.02^{\star} & 1_{1} \\
0.22,3.85\end{array}$ & $\begin{array}{ll}2.60^{\star} & 1_{03} \\
0.02,5.25 & \end{array}$ & $\begin{array}{l}-0.61 \quad 1_{2} \\
-3.94,2.84\end{array}$ & $\begin{array}{l}-1.10 \\
-6.26,4.34\end{array}$ \\
\hline & Cool season & $\begin{array}{l}-3.17^{\star \star} \quad 1_{1} \\
-5.44,-0.84\end{array}$ & $\begin{array}{l}-4.31^{\star} \\
-7.27,-1.26^{102}\end{array}$ & $\begin{array}{l}1.30^{\star \star} \\
0.38,2.23\end{array}$ & $1_{2}$ & $\begin{array}{l}2.26^{\star \star \star} \\
0.94,3.59\end{array}$ & $\begin{array}{ll}1.41 & 1_{1} \\
0.0,2.83 & \end{array}$ & $\begin{array}{ll}2.83^{\star \star} & 1_{03} \\
0.89,4.81 & \end{array}$ & $\begin{array}{l}1.66 \\
-0.04,3.37\end{array}$ & $\begin{array}{l}3.07^{\star} \\
0.65,5.56\end{array}$ \\
\hline
\end{tabular}

BS = black smoke.

${ }^{\star} \mathrm{p}<0.05,{ }^{\star \star} \mathrm{p}<0.01,{ }^{\star \star \star} \mathrm{p}<0.001$.

two days. The most significant single lag was selected whether the effect was positive or negative. We also examined the effect of cumulative lags up to three days. The effects of each air pollutant were examined for the whole year and for the "warm" (April to September) and "cool" (October to March) seasons separately. We analysed the effects of pollens in the warm season by either including all warm season days or only those days for which the pollen count was greater than zero. In examining the interaction between pollens and air pollutants we postulated a concurrent rather than sequential effect so that, in these models, the best respective lag for both pollen and pollutant was used. Where a pollutant was found to have a significant effect the effect of putting a second pollutant into the model was examined.

The results are presented as a percentage increase associated with a 10 unit increase in pollutant level. This was calculated by the formula $100 \times(1-\exp (\beta$ coefficient $\times 10)-1)$. A $1 \%$ relative increase corresponds to a relative risk of 1.01. A significance level of 5\% (two sided) is used.

\section{Results}

The descriptive statistics of the admissions and environmental data are shown in table 1 . The associations between the various air pollutants and asthma admissions are shown in table 2 by age and season. For the all-ages group over the whole year, significant associations were observed with $\mathrm{NO}_{2}, \mathrm{SO}_{2}$ and black smoke, with the cumulative lags tending to show stronger and more significant effects. Some of these associations have $\mathrm{p}$ values of $<0.001$ and provide good evidence for a relationship even after the Bonferroni correction for 24 tests (eight pollutants and three seasons).

Ozone was negatively associated with admissions in the $0-14$ age group (whole year and cool season) and positively with admissions in the 15-64 age group (whole year and warm season). The seasonal differences in the effects of ozone in these two age groups were statisti-

Table 3 Two pollutant models for those pollutants with significant associations in the single pollutant models. Effect of row pollutant when the column pollutant is entered into the model. Percentage change in admissions for 10 unit change in pollutant level (95\% confidence limits)

\begin{tabular}{|c|c|c|c|c|c|c|c|}
\hline Age (years) & Season & $\begin{array}{l}\text { Pollutant } \\
\text { (lag) }\end{array}$ & Single pollutant model & $8 \mathrm{hO}_{3}$ & $24 \mathrm{hNO}_{2}$ & $24 \mathrm{hSO}_{2}$ & $24 h B S$ \\
\hline \multirow[t]{5}{*}{$0-14$} & \multirow[t]{2}{*}{ All year } & $\mathrm{NO}_{2}(2)$ & $1.25(0.3,2.2)^{\star}$ & $1.13(-0.10,2.36)$ & - & $0.97(-0.05,1.99)$ & $2.26(0.83,3.71)^{\star \star \star}$ \\
\hline & & $\mathrm{SO}_{2}(1)$ & $1.64(0.29,3.01)^{\star}$ & $1.77(0.22,3.36)^{\star}$ & $1.23(-0.22,2.69)$ & - & $1.66(0.23,3.12)^{\star}$ \\
\hline & Warm & $\mathrm{SO}_{2}(1)$ & $3.33(1.09,5.63)^{\star \star}$ & $3.35(0.89,5.87)^{\star \star}$ & $2.92(0.58,5.32)^{\star}$ & - & $3.66(1.35,6.02)^{\star \star}$ \\
\hline & \multirow{2}{*}{ Cool } & $\mathrm{O}_{3}(0)$ & $-2.95(-5.80,-0.02)^{\star}$ & - & $-2.91(-5.77,0.03)$ & $-2.92(-5.80,0.04)$ & $-2.95(-5.81,-0.01)^{\star}$ \\
\hline & & $\mathrm{NO}_{2}(2)$ & $1.18(0.02,2.35)^{\star}$ & $0.91(-0.66,2.51)$ & - & $1.06(-0.17,2.29)$ & $1.84(-0.03,3.75)$ \\
\hline \multirow[t]{2}{*}{$15-64$} & All year & $\mathrm{O}_{3}(1)$ & $3.93(1.77,6.15)^{\star \star \star}$ & - & $4.00(1.83,6.22)^{\star \star \star}$ & $4.04(1.86,6.27)^{\star \star \star \star}$ & $3.96(1.78,6.18)^{\star \star \star}$ \\
\hline & Warm & $\mathrm{O}_{3}(1)$ & $4.25(1.83,6.74)^{\star \star \star}$ & - & $4.31(1.87,6.82)^{\star \star \star}$ & $4.82(2.28,7.42)^{\star \star \star}$ & $4.15(1.73,6.63)^{\star \star \star}$ \\
\hline \multirow[t]{4}{*}{$65+$} & \multirow[t]{2}{*}{ All year } & $\mathrm{NO}_{2}(2)$ & $2.96(0.67,5.31)^{\star \star}$ & $4.51(1.43,7.69)^{\star \star}$ & - & $2.49(-0.25,5.31)$ & $1.88(-1.49,5.36)$ \\
\hline & & $\mathrm{BS}(2)$ & $5.60(1.09,10.31)^{\star}$ & $7.56(1.19,14.34)^{\star}$ & $2.92(-3.56,9.85)$ & $4.56(-0.88,10.29)$ & - \\
\hline & \multirow[t]{2}{*}{ Cool } & $\mathrm{NO}_{2}(2)$ & $3.52(0.81,6.30)^{\star}$ & $5.14(0.69,9.79)^{\star}$ & - & $2.10(-1.08,5.39)$ & $4.47(-0.04,9.19)$ \\
\hline & & $\mathrm{SO}_{2}(2)$ & $5.85(1.81,10.05)^{\star \star}$ & $7.84(2.48,13.48)^{\star \star}$ & $4.19(-0.53,9.13)$ & - & $5.29(0.42,10.40)^{\star}$ \\
\hline \multirow[t]{7}{*}{ All ages } & \multirow[t]{2}{*}{ All year } & $\mathrm{NO}_{2}(2)$ & $1.25(0.49,2.02)^{\star \star \star}$ & $1.08(0.12,2.05)^{\star}$ & - & $0.99(0.18,1.81)^{\star}$ & $1.23(0.47,2.00)^{\star \star}$ \\
\hline & & $\mathrm{SO}_{2}(1)$ & $1.64(0.54,2.75)^{\star}$ & $1.48(0.24,2.73)^{\star}$ & $1.14(-0.04,2.33)$ & - & $1.54(0.36,2.73)^{\star}$ \\
\hline & \multirow{2}{*}{ Warm } & $\mathrm{O}_{3}(1)$ & $2.21(0.62,3.82)^{\star \star}$ & - & $1.97(0.35,3.62)^{\star}$ & $1.99(0.40,3.61)^{\star}$ & $2.18(0.59,3.79)^{\star \star}$ \\
\hline & & $\mathrm{SO}_{2}(1)$ & $2.02(0.22,3.85)^{\star}$ & $1.91(0.05,3.81)^{\star}$ & $1.64(-0.23,3.56)$ & - & $2.18(0.32,4.07)^{\star}$ \\
\hline & \multirow[t]{3}{*}{ Cool } & $\mathrm{O}_{3}(1)$ & $-3.17(-5.44,0.84)^{\star \star}$ & & $-2.90(-5.26,-0.49)^{\star}$ & $-3.01(-5.36,-0.60)^{\star}$ & $-2.92(-5.24,-0.54)^{\star}$ \\
\hline & & $\mathrm{NO}_{2}(2)$ & $1.30(0.38,2.23)^{\star \star}$ & $0.50(-0.79,1.81)$ & - & $1.10(0.12,2.08)^{\star}$ & $1.29(0.37,2.22)^{\star \star}$ \\
\hline & & $\mathrm{SO}_{2}(1)$ & $1.41(1.00,2.83)^{\star}$ & $-0.09(-1.61,1.82)$ & $0.83(-0.67,2.34)$ & - & $1.11(-0.41,2.66)$ \\
\hline
\end{tabular}

BS $=$ black smoke

${ }^{\star} \mathrm{p}<0.05 ;{ }^{\star \star} \mathrm{p}<0.01 ;{ }^{\star \star \star} \mathrm{p}<0.001$. 
Table 4 Percentage increase in daily asthma admissions associated with 10 unit increase in pollen grain counts during the warm season in London, 1987-91. 95\% confidence limits are shown in parenthesis together with the corresponding lag period $\left(l_{x}\right)$. Where a statistically significant association was observed for other lags, these are shown in parentheses

\begin{tabular}{lllllll}
\hline Age group & Birch pollen & \multicolumn{3}{c}{ Grass pollen } & \multicolumn{2}{c}{ Oak pollen } \\
\hline 0-14 years & $0.90^{\star}(0.14,1.67)$ & $1_{2}$ & $-1.13^{\star}(-1.96,0.0)$ & $1_{0}$ & $-1.62^{\star}(-3.21,0.0)$ & $1_{0(1)}$ \\
15-64 years & $1.11^{\star}(0.11,2.12)$ & $1_{1}$ & $-0.073(-1.71,0.26)$ & $1_{1}$ & $1.89^{\star}(0.0,3.80)$ & $1_{1}$ \\
65+ years & $-0.77(-3.37,1.9)$ & $1_{0}$ & $-0.63(-2.69,1.48)$ & $1_{0}$ & $-2.6(-6.37,1.31)$ & $1_{1}$ \\
All ages & $0.78^{\star}(0.15,1.42)$ & $1_{2(1)}$ & $-1.16^{\star \star \star}(-1.82,-0.5)$ & $1_{0}$ & $-1.44^{\star}(-2.71,-1.04)$ & $1_{0(1)}$ \\
\hline
\end{tabular}

cally significant. $\mathrm{NO}_{2}$ was significantly associated with admissions in the 0-14 age group (whole year and warm season) and in the 65+ age group (cool season). $\mathrm{SO}_{2}$ was associated with admissions in the $0-14$ age group (whole year and warm season) and in the 65+ age group (cool season), while black smoke was associated with admissions in the 65+ age group (whole year and cool season).

The various pollutants covary to some extent and this covariation is not constant across the seasons. For example, the correlation between ozone and $\mathrm{NO}_{2}$ is positive in the warm season and negative in the cool season. For every significant association, two-pollutant models were examined to obtain insight into which single pollutant might influence asthma admissions independently of the effects of others. The results of this analysis are shown in table 3. The results did not follow a pattern that is easy to summarise. We draw attention to those analyses in which the effect of a particular pollutant remained significant after each of the other three pollutants was included in the model.

In the all-year analysis the effects of $\mathrm{O}_{3}$ (15-64 age group) and $\mathrm{NO}_{2}$ (all-ages) were robust to inclusion of each of the other three pollutants. In the warm season analysis similarly robust findings were obtained for $\mathrm{SO}_{2}$ (0-14 age group) and ozone (15-64 age group and all-ages). In the cool season the only robust result was for the negative effect of ozone in the all-ages analysis.

The effect of birch, grass, and oak pollens on admissions is shown in table 4 . No consistent pattern is apparent. There is a significant positive effect of birch pollen in the $0-14$ and 15-64 age groups, a significant negative effect of grass pollen in the $0-14$ age group, and a significant negative effect of oak pollen in the 0-14 and 15-64 age groups. Because the production and dispersal of pollens is related to weather conditions, it is possible that any effects of pollens on asthma admissions could confound the effects of pollutants in the relevant period of the year. There was little correlation between birch pollen and any pollutant but grass pollen was correlated positively with ozone $(r=0.122)$ and $\mathrm{SO}_{2}(r=$ $0.115)$ and negatively with black smoke $(r=$ $-0.117)$. Oak pollen was positively related to ozone $(r=0.138)$ and $\mathrm{NO}_{2}(r=0.182)$.

To examine the possibility of confounding by pollens the effects of those pollutants found to have warm season effects were examined after inclusion of each of the pollen categories in the model. As table 5 clearly shows, the pollutant effects are not influenced by introducing pollen into the model. The analysis was repeated for only those days on which the pollen count was above zero with the same result. Table 6 tests the hypothesis that there is a pollution/pollen interaction by comparing the effects of pollutants on days when pollens were present with those when they were not. The only interaction in a positive direction-that is, as hypothesised-was between $\mathrm{SO}_{2}$ and grass pollen in the $0-14$ age group $(\mathrm{p}<0.01)$. In two comparisons (ozone and birch pollen and ozone and oak pollen in the all-age group) the

Table 5 Results of two pollutant models examining the effect of pollen on estimates of individual pollutant effects. Analysis is confined to the warm season, and to pollutants which were significant in the unipollutant models (see table 2)

\begin{tabular}{llllll}
\hline Age (years) & Pollutant (lag) & Single pollutant effect & Birch & Grass & Oak \\
\hline $0-14$ & $24 \mathrm{~h} \mathrm{SO}_{2}(1)$ & $3.33^{\star \star}$ & $3.17(0.92,5.47)^{\star \star}$ & $3.30(1.05,5.59)^{\star \star}$ & $3.34(1.0,5.63)^{\star \star}$ \\
$15-64$ & $8 \mathrm{~h} \mathrm{O}_{3}(1)$ & $4.25^{\star \star \star}$ & $4.30(1.88,6.78)^{\star \star \star}$ & $4.28(1.86,6.76)^{\star \star \star}$ & $4.16(1.74,6.64)^{\star \star \star}$ \\
& $24 \mathrm{~h} \mathrm{SO}_{2}(2)$ & -1.39 & $-1.62(-4.21,1.04)$ & $-1.36(-3.96,1.30)$ & $-1.34(-3.93,1.32)$ \\
All ages & $8 \mathrm{~h} \mathrm{O}_{3}(1)$ & $2.21^{\star \star}$ & $2.23(0.64,3.83)^{\star \star}$ & $2.24(0.66,3.85)^{\star \star}$ & $2.22(0.64,3.83)^{\star \star}$ \\
& $24 \mathrm{~h} \mathrm{SO}_{2}(1)$ & $2.02^{\star}$ & $1.82(0.02,3.65)^{\star}$ & $2.10(0.30,3.93)^{\star}$ & $2.01(0.22,3.84)^{\star}$ \\
\hline
\end{tabular}

Table 6 Results of two pollutant models examining the effect of pollen on estimates of individual pollutant effects. Analysis is confined to the warm season and to pollutants which were significant in the unipollutant models

\begin{tabular}{|c|c|c|c|c|c|}
\hline Age (years) & Pollutant (lag) & Days & Birch & Grass & Oak \\
\hline \multirow[t]{5}{*}{$0-14$} & \multirow[t]{3}{*}{$8 \mathrm{~h} \mathrm{O}_{3}(0)$} & Pollen $>0$ & $-0.47(-4.39,3.61)$ & $0.94(-1.31,3.23)$ & $-1.26(-5.30,2.95)$ \\
\hline & & No pollen & $1.83(-0.33,4.03)$ & $2.66(-0.43,5.85)$ & $2.07(-0.09,4.27)$ \\
\hline & & & & & $3.34(1.0,5.63)^{\star \star}$ \\
\hline & \multirow[t]{2}{*}{$24 \mathrm{~h} \mathrm{SO}_{2}(1)$} & Pollen $>0$ & $3.51(-1.20,8.45)$ & $5.78(3.04,8.59)^{\star \star \star 1}$ & $3.99(-0.58,8.76)$ \\
\hline & & No pollen & $3.27(0.87,5.73)^{\star \star}$ & $0.14(-2.97,3.34)$ & $3.21(0.84,5.63)^{\star \star}$ \\
\hline \multirow[t]{4}{*}{$15-64$} & \multirow[t]{2}{*}{$8 \mathrm{~h} \mathrm{O}_{3}(1)$} & Pollen $>0$ & $2.79(-1.95,7.76)$ & $4.64(1.98,7.37)^{\star \star \star}$ & $1.42(-3.43,6.51)$ \\
\hline & & No pollen & $4.62(2.00,7.30)^{\star \star \star}$ & $3.12(-1.01,7.43)$ & $4.83(2.24,7.50)^{\star \star \star}$ \\
\hline & \multirow{2}{*}{$24 \mathrm{~h} \mathrm{SO}_{2}(2)$} & Pollen $>0$ & $0.99(-4.38,6.66)$ & $-1.12(-4.15,2.01)$ & $-2.54(-7.74,2.96)$ \\
\hline & & No pollen & $-1.56(-4.36,1.33)$ & $-1.89(-5.62,1.99)$ & $-1.15(-3.89,1.67)$ \\
\hline \multirow[t]{4}{*}{ All ages } & \multirow{2}{*}{$8 \mathrm{~h} \mathrm{O}_{3}(1)$} & Pollen $>0$ & $-2.81(-5.84,0.31)^{2}$ & $2.20(0.45,3.98)^{\star \star}$ & $-2.69(-5.82,0.54)^{3}$ \\
\hline & & No pollen & $3.38(1.67,5.12)^{\star \star \star}$ & $2.34(-0.21,4.95)$ & $3.27(1.57,5.00)^{\star \star \star}$ \\
\hline & \multirow[t]{2}{*}{$24 \mathrm{~h} \mathrm{SO}_{2}(1)$} & Pollen $>0$ & $2.44(-1.40,6.44)$ & $3.19(1.05,5.38)^{\star \star}$ & $1.09(-2.55,4.87)$ \\
\hline & & No pollen & $2.00(0.08,3.96)^{\star \star}$ & $0.27(-2.28,2.89)$ & $2.20(0.29,4.14)^{\star}$ \\
\hline
\end{tabular}

${ }^{1}$ Interaction $\mathrm{p}<0.01 ;{ }^{2}$ interaction $\mathrm{p}<0.001{ }^{3}$ interaction $\mathrm{p}<0.001$. 
Table 7 Summary of time series studies of air pollution and daily admissions or emergency room attendance for asthma. The rows are sorted by whether the analysis was for "all year" (including across seasons) and by "summer" (warm half of the year) or "winter" (cool half of the year). Under the various age groups where a pollutant is within a parenthesis, the association was negative

\begin{tabular}{|c|c|c|c|c|c|c|c|c|c|c|c|c|c|c|}
\hline Author & $\begin{array}{l}\text { Reference } \\
\text { no. }\end{array}$ & Year & Place & $\begin{array}{l}A d s / \\
E R\end{array}$ & Season & Months & $\mathrm{O}_{3}$ & $\mathrm{NO}_{2}$ & $\mathrm{SO}_{2}$ & Particles & $0-14$ yrs & $15-64 y r s$ & $65+y r s$ & All ages \\
\hline Anderson & This paper & & London & Ads & $\mathrm{AY}$ & & + & + & + & BS & $\mathrm{NO}_{2}, \mathrm{SO}_{2}$ & $\mathrm{O}_{3}$ & $\mathrm{NO}_{2}, \mathrm{BS}$ & $\mathrm{NO}_{2}, \mathrm{SO}_{2}, \mathrm{BS}$ \\
\hline Buchdahl & 20 & 1996 & London & ER & AY & & + & + & + & - & $\mathrm{O}_{3}, \mathrm{SO}_{2}$ & - & - & \\
\hline $\mathrm{Dab}$ & 21 & 1996 & Paris & Ads & AY & & + & + & + & $\mathrm{PM}_{13}, \mathrm{BS}$ & $\mathrm{SO}_{2}$ & $\mathrm{O}_{3}, \mathrm{NO}_{2}$ & - & $\mathrm{SO}_{2}, \mathrm{NO}_{2}$ \\
\hline Ponka & 22 & 1996 & Helsinki & Ads & $\mathrm{AY}$ & & + & + & + & TSP & $\mathrm{NS}^{2}$ & & $\mathrm{SO}_{2}$ & - \\
\hline Romieu & 23 & 1995 & $\begin{array}{l}\text { Mexico } \\
\text { City }\end{array}$ & ER & $\mathrm{AY}$ & Jan-Jun & + & - & + & - & $\mathrm{O}_{3}, \mathrm{SO}_{2}$ & - & - & - \\
\hline Schwartz & 24 & 1993 & Seattle & ER & $\mathrm{AY}$ & & + & - & + & $\mathrm{PM}_{10}$ & $\mathrm{PM}_{10}$ & $\mathrm{PM}_{10}$ & NS & - \\
\hline Sunyer & 14 & 1996 & Barcelona & ER & AY & & + & + & + & BS & - & $\mathrm{O}_{3}$ & - & - \\
\hline Anderson & This paper & & London & Ads & $\mathrm{S}$ & Apr-Sept & + & + & + & BS & $\mathrm{O}_{3}, \mathrm{NO}_{2}, \mathrm{SO}_{2}$ & $\mathrm{O}_{3}$ & NS & $\mathrm{O}_{3}, \mathrm{SO}_{2}$ \\
\hline Bates & 25 & 1990 & Vancouver & ER & $\mathrm{S}$ & & + & + & + & $\mathrm{SO}_{4}, \mathrm{COH}$ & $\mathrm{SO}_{4}$ & $\mathrm{SO}_{2}, \mathrm{SO}_{4}$ & $\mathrm{SO}_{4}$ & \\
\hline Bates & 26 & 1987 & Ontario & Ads & $\mathrm{S}$ & July-Aug & + & + & + & $\mathrm{SO}_{4}, \mathrm{COH}$ & NS & & - & $\mathrm{SO}_{2}, \mathrm{O}_{3}, \mathrm{SO}_{4}$ \\
\hline Burnett & 27 & 1994 & Ontario & Ads & $S$ & May-Aug & + & - & - & $\mathrm{SO}_{4}$ & $\mathrm{O}_{3} \mathrm{SO}_{4}$ & $\mathrm{O}_{3} \mathrm{SO}_{4}$ & NS & $\mathrm{O}_{3}, \mathrm{SO}_{4}$ \\
\hline Castellsague & 28 & 1995 & Barcelona & ER & $S$ & & + & + & + & BS & - & $\mathrm{BS}, \mathrm{NO}_{2}$ & $\mathrm{BS}, \mathrm{NO}_{2}$ & - \\
\hline Cody & 29 & 1992 & N Jersey & ER & S & May-Aug & + & - & + & - & - & - & - & $\mathrm{O}_{3}$ \\
\hline Delfino & 30 & 1994 & Montreal & Ads & $\mathrm{S}$ & Jun-Sept & + & - & - & $\begin{array}{l}\mathrm{PM}_{10}, \mathrm{PM}_{2} \\
\mathrm{H}^{+}, \mathrm{SO}_{4}\end{array}$ & ${ }_{5}-$ & - & - & $\mathrm{PM}_{10}, \mathrm{SO}_{4}$ \\
\hline Schouten & 31 & 1996 & Amsterdam & Ads & $S$ & Apr-Sept & + & + & + & BS & - & - & - & $\mathrm{SO}_{2}$ \\
\hline Steib & 32 & 1996 & St John, NB & ER & $\mathrm{S}$ & May-Sept & + & + & + & $\mathrm{SO}_{4}, \mathrm{TSP}$ & NS & $\mathrm{O}_{3}$ & $\mathrm{O}_{3}$ & \\
\hline Thurston & 33 & 1994 & Toronto & Ads & $\mathrm{S}$ & & + & - & - & $\mathrm{SO}_{4}, \mathrm{H}^{+}$ & - & - & - & $\mathrm{O}_{3}, \mathrm{SO}_{4}, \mathrm{H}^{+}$ \\
\hline Thurston & 34 & 1992 & New York & Ads & $\mathrm{S}$ & & + & - & - & $\mathrm{SO}_{4}, \mathrm{H}^{+}$ & - & - & - & $\mathrm{O}_{3}, \mathrm{SO}_{4}, \mathrm{H}^{+}$ \\
\hline Walters & 35 & 1994 & B'ham, UK & Ads & $S$ & June-Aug & - & - & + & BS & - & - & - & NS \\
\hline Anderson & This paper & & London & Ads & W & Oct-Mar & + & + & + & BS & $\left(\mathrm{O}_{3}\right), \mathrm{NO}_{2}$ & NS & $\mathrm{NO}_{2}, \mathrm{SO}_{2}, \mathrm{BS}$ & $\left(\mathrm{O}_{3}\right), \mathrm{NO}_{2}, \mathrm{SO}_{2}, \mathrm{BS}$ \\
\hline Bates & 25 & 1990 & Vancouver & ER & $\mathrm{W}$ & & + & + & + & $\mathrm{SO}_{4}, \mathrm{COH}$ & NS & NS & $\mathrm{SO}_{2}, \mathrm{SO}_{4}$ & - \\
\hline Bates & 26 & 1987 & Ontario & Ads & W & Jan-Feb & + & + & + & $\mathrm{SO}_{4}, \mathrm{COH}$ & $\left(\mathrm{O}_{3}\right)$ & - & - & NS \\
\hline Castellsague & 28 & 1995 & Barcelona & ER & W & & + & + & + & BS & - & $\mathrm{NO}_{2}$ & - & - \\
\hline Schouten & 31 & 1996 & Amsterdam & Ads & $\mathrm{W}$ & Oct-Mar & + & + & + & BS & - & - & - & NS \\
\hline Walters & 35 & 1994 & B'ham, UK & Ads & W & Dec-Feb & - & - & + & BS & - & - & - & $\mathrm{BS}, \mathrm{SO}_{2}$ \\
\hline
\end{tabular}

Ads = admissions; ER = emergency room admissions or attendance at accident and emergency departments; TSP = total suspended particles; PM = suspended particles; $\mathrm{SO}_{4}=$ sulphate; $\mathrm{COH}=$ coefficient of haze; $\mathrm{H}^{+}=$hydrogen ion concentration (a measure of acid aerosols); $\mathrm{AY}=$ all year; $\mathrm{S}=$ summer/warm season; $\mathrm{W}=$ winter/cool season; $\mathrm{BS}=$ black smoke; NS = no pollutant significant, $-=$ no information on that age group.

interaction was significantly negative $(\mathrm{p}<0.001$ in each case).

\section{Discussion}

This is one of the most comprehensive investigations of daily asthma admissions and air pollution yet reported, and one of the few to take airborne pollen into account and to examine interactions between pollution and pollen levels. We found associations between all of the four air pollutants and daily asthma admissions, but a lack of consistency across age groups and seasons. Some of the associations were not strongly significant and others were weakened or became non-significant after including another pollutant in the model. For all ages combined the most robust associations were with $\mathrm{SO}_{2}$ and $\mathrm{NO}_{2}$. When analysed by age the most robust associations were for $\mathrm{SO}_{2}$ in the warm season in children, and for ozone in younger adults, also in the warm season. With the exception of ozone, there was a tendency for the cumulative lags to have a stronger effect.

Although the statistical method employed was a widely accepted one,${ }^{13}$ its appropriateness and the manner in which potential confounders, especially weather and cyclical factors, are controlled have both been criticised. ${ }^{18}$ Studies which have addressed these issues in the context of daily mortality have been reassuring ${ }^{19}$ but may be less relevant to admission data which may require more complex models than mortality data. This applies especially to children because of their greater susceptibility to respiratory epidemics and the effects of school holidays. In addition, it must also be recognised that large numbers of statistical tests were performed using a variety of lags, and it is therefore also possible that some of the significant results were due to chance. For this reason more weight should be placed on the larger and more strongly significant findings, especially those which are consistent across seasons and age groups and robust to the inclusion of other pollutants in the model.

Our assessment of exposure was based on a relatively small number of monitors and may not have been a good indicator of personal exposure to outdoor pollution. Where several monitors were available, there was a significant and often strong correlation between them. Since this study the number of automatic monitors in London has expanded greatly. These new monitors, which cover both central and suburban London, tend to show good tracking between background levels of ozone, $\mathrm{NO}_{2}$ and $\mathrm{PM}_{10}$ particles, though less so for $\mathrm{SO}_{2}$.

Twenty one other studies of air pollution and daily asthma admissions were identified in the literature. Of these, 15 appeared to have a satisfactory methodology and these, together with the present study, are listed in table 7 to obtain an overview of age groups and pollutants studied and the direction and statistical significance of the associations reported. Calculation of summary estimates using meta-analysis was outside the scope of this paper and would, in any case, have been difficult because the studies differed in many respects, including methods, statistical power, the pollutants investigated, and the age ranges reported. Our assessment of consistency will rely mainly on whether statistically significant findings were reported. In the all-age group three of 14 studies did not find significant associations with any of the pollutants assessed and the proportions with significant findings for ozone, $\mathrm{SO}_{2}, \mathrm{NO}_{2}$ and particles were $7 / 14,6 / 12,2 / 9$, and $7 / 15$, respectively. For the adult age group (15-64) three out of 13 did not find significant associations and the proportions with significant asso- 
ciations with ozone, $\mathrm{SO}_{2}, \mathrm{NO}_{2}$ and particles were $6 / 13,1 / 12,3 / 13$, and $3 / 13$, respectively. One of the ozone associations was negative. Similarly, in children, 4/13 did not find significant associations and the proportions with significant associations with ozone, $\mathrm{SO}_{2}, \mathrm{NO}_{2}$ and particles were $6 / 11,5 / 12,3 / 13$, and $2 / 11$, respectively. Two of the associations with ozone were negative (both in the winter season). Taken overall, it is apparent that the evidence is not coherent as to whether there is an effect of pollution or the responsible pollutant. Ozone, $\mathrm{SO}_{2}$ and particles were significant in no more than half of all studies and only about a quarter found significant effects for $\mathrm{NO}_{2}$.

Some of this inconsistency may result from false negative results arising from lack of statistical power or from false positive results due to chance, multiple significance testing, post hoc hypothesis testing, or publication bias. It could also result from differences between cities in the pollutant levels and prevailing mixtures. Differences between the age-specific results may also reflect differences in the clinical and pathological nature of asthma and its provoking factors at different stages of life. Many of the pollutants considered were not independent of one another and may have been indicating some other causal pollutant which was not measured. For example, summer pollution comprises a complex mixture and varying relationships of gaseous pollutants such as ozone and $\mathrm{SO}_{2}$ and secondary particles such as sulphates, nitrates and associated acids. Significant associations between hospital admissions for asthma and individual pollutants should not therefore be interpreted narrowly as necessarily being an effect of that pollutant. Conversely, the lack of strong associations with black smoke does not exclude an effect of particles such as sulphates not measured by this technique.

Debate about the causal nature of associations between daily mortality and particle pollution has been dominated by issues of methodology, potential confounding, and biological plausibility. A major argument in favour of causality has been the consistency of results obtained from a wide variety of cities throughout the world. In the case of asthma admissions lack of consistency weakens the argument for causality. Perhaps the effects of outdoor air pollution on asthma admissions are more dependent on local environments and population vulnerability than is the case for particles and mortality. If this is the case, results from one area should not be assumed to apply to another.

Hospital admissions for asthma may also be influenced by ambient aeroallergens. Extreme examples are point source epidemics such as those associated with the unloading of soy beans ${ }^{36}$ and with rye grass pollen in association with thunderstorms. ${ }^{37}$ The rise in admissions in the spring has been attributed to pollens. ${ }^{38} \mathrm{~A}$ number of studies have not found associations between pollens and daily admissions or emergency room attendances for asthma. ${ }^{39-41}$ One explanation could be that pollens are generally too large to penetrate to the small airways. On the other hand, fungal spores which are smaller (and hence more respirable) have been associated with asthma admissions. ${ }^{41}{ }^{42}$ In the present study we are confident that the observed associations between admissions and air pollutants are most unlikely to have been confounded by pollens. It also seems unlikely that there is an interaction between pollens and air pollutants. Further work with more recent data will investigate whether the same is true for airborne fungal spores.

Chamber studies have found evidence of interactions between aeroallergens and gaseous ambient pollutants in their effects on bronchial hyperresponsiveness. ${ }^{8-10} 43$ We found little evidence to suggest that this mechanism occurs in the ambient situation, apart from the interaction between $\mathrm{SO}_{2}$ and grass pollen in children's asthma admissions which requires confirmation in further studies. The chamber study of Devalia $e t a l^{43}$ found evidence of an interaction between pollens and a mixture of $\mathrm{NO}_{2}$ and $\mathrm{SO}_{2}$ but we did not address the question of interactions with mixtures in this data set.

We conclude that there is evidence that all of the pollutants may have an effect on asthma admissions but that there is a lack of consistency across the age groups in the specific pollutant responsible. Associations with pollutants were not confounded by airborne pollens and there was little evidence for an interaction with pollens. These results, when taken together with 15 published studies of air pollution and daily asthma admissions, indicate that the evidence linking air pollution to asthma admissions lacks consistency.

This study was funded by the National Asthma Campaign (Grant 178) and the European Commission, DGXII, Environment 1991-94 Programme (EV5V CT92-0202).

1 American Thoracic Society. Health effects of outdoor air pollution. Am ₹ Respir Crit Care Med 1996;153:3-50.

2 Department of Health Committee on the Medical Effects of Air Pollutants. Asthma and outdoor air pollution. London: Air Pollutants. A

3 British Society for Allergy and Clinical Immunology. Air pollution and allergic disease. Clin Exp Allergy 1995; 25(Supplement 3)

4 Brunekreef B, Dockery DW, Krzyzanowski M. Epidemiologic studies on short-term effects of low levels of major ambient air pollution components. Environ Health Perspect 1995;103(Suppl 2):3-13

5 Whittemore AS. Asthma and air pollution in the Los Angeles area. Am F Public Health 1980;70:687-97.

6 Schwartz J, Zeger S. Passive smoking, air pollution, and acute respiratory symptoms in a diary study of student nurses. Am Rev Respir Dis 1990;141:62-7.

7 Romieu I, Meneses F, Ruiz S, et al. Effects of air pollution on the respiratory health of asthmatic children living in
Mexico City. Am $\mathcal{F}$ Respir Crit Care Med 1996;154:300-7.

8 Molfino NA, Wright SC, Katz I, et al. Effect of low concentrations of ozone on inhaled allergen responses in asthmatic trations of ozone on inhaled allergen
subjects. Lancet 1991;338:199-203.

9 Tunnicliffe WS, Burge PS, Ayres JG. Effect of domestic concentrations of nitrogen dioxide on airway responses to inhaled allergen in asthmatic patients. Lancet 1994;44: inhaled $1733-6$.

10 Jorres R, Nowak D, Magnussen H. The effect of ozone exposure on allergen responsiveness in subjects with asthma or rhinitis. Am f Respir Crit Care Med 1996;153:5664.

11 Katsouyanni K, Zmirou D, Spix C, et al. Short-term effects of air pollution on health: a European approach using epidemiological time-series data. The APHEA project: background, objectives, design. Eur Respir f 1995;8:10308.

12 Katsouyanni K, Schwartz J, Spix C, et al. Short term effects of air pollution on health: a European approach using epi-
demiologic time series data: the APHEA protocol. $\mathcal{F}$ Epidemiol Community Health 1996;50(Suppl 1):S12-8.

13 Schwartz J, Spix C, Touloumi G, et al. Methodological issues in studies of air pollution and daily counts of deaths or hospital admissions. $\mathcal{F}$ Epidemiol Community Health 1996;50(Suppl 1):S3-11. 
14 Sunyer J, Spix C, Quenel P, et al. Urban air pollution and emergency admissions for asthma in four European cities:

15 Ponce de Leon A, Anderson HR, Bland JM et al. Effects of air pollution on daily hospital admissions for respiratory disease in London between 1987-88 and 1991-92. F Epidemiol Community Health 1996;50(Suppl 1):s63-70.

16 Quality of Urban Air Review Group. Airborne particulate matter in the United Kingdom. Birmingham: University of Birmingham, 1996.

17 Buck SF. A method of estimation of missing values in multivariate data suitable for use with an electronic computer. fR Stat $\operatorname{Soc}(B)$ 1960;22:302-6.

18 Moolgavkar SH, Luebeck EG, et al. Air pollution and daily mortality in Philadelphia. Epidemiology 1995;6:476-84.

19 Health Effects Institute. Particulate air pollution and daily mortality. Replication and validation of selected studies. Phase 1 report of the particle epidemiology evaluation Phase 1 report of the particle epidemiology evaluation
project. Cambridge MA: Health Effects Institute, 1995.

20 Buchdahl R, Parker A, Stebbings T, et al. Association between air pollution and acute childhood wheezy between air pollution and acute childhood wheezy episodes:

21 Dab W, Medina S, Quenel P, et al. Short term respiratory health effects of ambient air pollution: results of the APHEA project in Paris. $\mathcal{F}$ Epidemiol Community Health 1996;50 (Suppl 1):s42-6.

22 Ponka A, Virtanen M. Asthma and ambient air pollution in Helsinki. $\mathcal{F}$ Epidemiol Community Health 1996;50(Supp 1): $559-62$.

23 Romieu I, Meneses F, Sienra-Monge JJ, et al. Effects of urban air pollutants on emergency visits for childhood asthma in Mexico City. Am 7 Epidemiol 1995;141:546-53.

24 Schwartz J, Slater D, Larson TV, et al. Particulate air pollution and hospital emergency room visits for asthma in Seattle. Am Rev Respir Dis 1993;147:826-31.

25 Bates DV, Baker-Anderson M, Sizto R. Asthma attack periodicity: a study of hospital emergency visits in Vancouperiodicity: a study of hospital en

26 Bates DV, Sizto R. Air pollution and hospital admissions in Southern Ontario: the acid summer haze effect. Environ Res 1987;43:317-31.

27 Burnett R, Dales RE, Raizenne ME, et al. Effects of low ambient levels of ozone and sulphates on the frequency of respiratory admissions to Ontario hospitals. Environ Res 1994;65:172-94

28 Castellsague J, Sunyer J, Saez M, et al. Short-term association between air pollution and emergency room visits for asthma in Barcelona. Thorax 1995;50:1051-6.

29 Cody RP, Weisel CP, Birnbaum G, et al. The effect of ozone associated with summertime photochemical smog on the frequency of asthma visits to hospital emergency departments. Environ Res 1992;58:184-94.
30 Delfino RJ, Becklake MR, Hanley JA. The relationship of urgent hospital admissions for respiratory illnesses to photochemical air pollution levels in Montreal. Environ Res 1994;67:1-19.

31 Schouten JP, Vonk JM, de Graaf A. Short term effects of air pollution on emergency hospital admissions for respiratory disease: results of the APHEA project in two major cities in The Netherlands, 1977-1989. F Epidemiol Community Health 1996;50(Suppl 1):S22-9.

32 Stieb DM, Burnett RT, Beveridge RC, et al. Association between ozone and asthma emergency department visits in Saint John, New Brunswick, Canada. Environ Health Perspect 1996;104:1354-60.

33 Thurston GD, Ito K, Hayes CG, et al. Respiratory hospital admissions and summertime haze air pollution in Toronto, Ontario: consideration of the role of acid aerosols. Environ Res 1994;65:271-90.

34 Thurston GD, Ito K, Kinney PL, et al. A multi-year study of air pollution and respiratory hospital admissions in three New York State metropolitan areas: results for 1988 and 1989 summers. 7 Expos Anal Environ Epidemiol 1992;2: 429-50.

35 Walters S, Griffiths RK, Ayres J. Temporal association between hospital admissions for asthma in Birmingham and ambient levels of sulphur dioxide and smoke. Thorax 1994;49:133-40.

36 Anto JM, Sunyer J, Rodriguez-Roison R, et al. Community outbreaks of asthma associated with inhalation of soybean dust. N Engl F Med 1989;320:1097-102.

37 Knox RB. Grass pollen, thunderstorms and asthma. Clin Exp Allergy 1993;23:354-9.

38 Khot A, Burn R, Evans N, et al. Seasonal variation and time trends in childhood asthma in England and Wales 1975-81. BMF 1984;289:235-7.

39 Schramm R, Graffino D, Grubman S, et al. Air pollutants, pollen counts and pediatric ER visits for asthma in an inner city hospital (abstract). F Allergy Clin Immunology 1992; 89(1 Part 2):250.

40 Rossi OVJ, Kinnula VL, Tienari J, et al. Association of severe asthma attacks with weather, pollen, and air pollutants. Thorax 1993;48:244-8.

41 Delfino RJ. Daily asthma severity in relation to personal ozone exposure and outdoor fungal spores. Am $\mathcal{f}$ Respir Crit Care Med 1996;154:633-41.

42 Neas LM, Dockery DW, Burge H, et al. Fungus spores, air pollutants, and other determinants of peak expiratory flow rate in children. Am f Epidemiol 1996;143:797-807.

43 Devalia JL, Rusznak C, Herdman MJ, et al. Effect of nitrogen dioxide and sulphur dioxide on airway response of mild asthmatic patients to allergen inhalation. Lancet 1994;344: $1668-71$. 